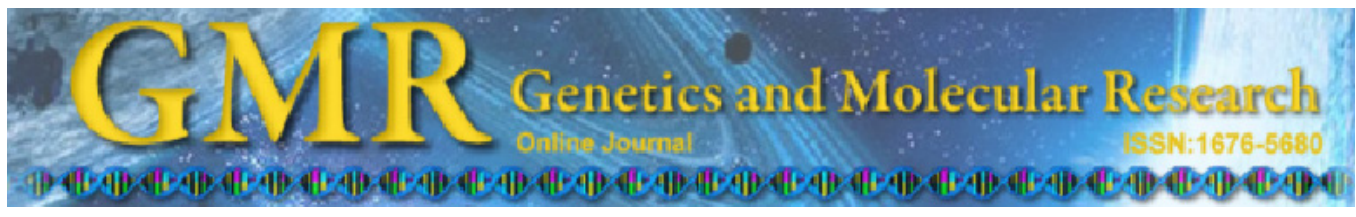

\title{
Evaluation of genetic diversity and population structure in a commercially important freshwater fish Prochilodus costatus (Characiformes, Prochilodontidae) using complex hypervariable repeats
}

\author{
T.M. Barroca ${ }^{1}$, G.B. Santos ${ }^{2}$, N.V.R. Duarte ${ }^{2}$ and E. Kalapothakis ${ }^{1}$ \\ ${ }^{1}$ Laboratório de Biotecnologia e Marcadores Moleculares, \\ Departamento de Biologia Geral, Instituto de Ciências Biológicas, \\ Universidade Federal de Minas Gerais, Belo Horizonte, MG, Brasil \\ ${ }^{2}$ Programa de Pós-Graduação em Zoologia de Vertebrados, \\ Pontifícia Universidade Católica de Minas Gerais, Belo Horizonte, MG, Brasil \\ Corresponding author: E. Kalapothakis \\ E-mail: ekalapo@icb.ufmg.br
}

Genet. Mol. Res. 11 (4): 4456-4467 (2012)

Received March 23, 2012

Accepted June 7, 2012

Published September 27, 2012

DOI http://dx.doi.org/10.4238/2012.September.27.4

\begin{abstract}
We used complex hypervariable repeats to evaluate the genetic diversity and structure of Prochilodus costatus (Characiformes), an ecologically and economically important species endemic to the São Francisco River basin. Hydroelectric dams along the river have led to population fragmentation, which can limit gene flow. Restocking from hatcheries has been used to repopulate declining populations. To determine how fragmentation and hatchery supplementation affect $P$. costatus population structure, we studied populations from three sites up and downstream of the Gafanhoto Dam (Pará River, State of Minas Gerais). High levels of genetic diversity were found within populations $(0.926$ to 0.873$)$; the three populations showed significant differentiation $\left(F_{\mathrm{ST}}=0.16\right)$, suggest-
\end{abstract}


ing that populations from the three sites were affected by fragmentation of the river and by hatchery contributions. These results will be useful for developing a management and conservation plan for fish species in this area.

Key words: Freshwater fish; Prochilodus costatus; Genetic diversity; Complex hypervariable repeats; Population genetic structure;

Hatchery program

\section{INTRODUCTION}

Prochilodus species are among the most conspicuous, abundant, and widely distributed freshwater fishes in South American rivers. These species are important for commercial and subsistence freshwater fishing in many parts of the continent; in some regions, they constitute $50-90 \%$ of the total fish biomass (Welcomme, 1979; Bowen, 1983; Bonetto, 1986; Sivasundar et al., 2000). During the high rainy season, most of these fishes migrate long distances upstream to spawning areas close to the headwaters. They spawn all eggs at once in the open waters of the main river channel, and larvae drift passively toward flooded areas (Agostinho et al., 1993). In Brazil, the São Francisco River Basin is the habitat of 152 fish species, including the highly abundant and ecologically and economically important Prochilodus costatus (Valenciennes, 1850) that is known locally as curimbatá-pioa (Sato and Godinho, 2003). This long-distance migratory species plays an important ecological role by cycling organic material and an important economic role in artisanal and commercial fishing communities (Flecker, 1996; De Camargo and Petrere Jr., 2001). As a result, $P$. costatus should be the focus of reproductive management and conservation programs in this region.

Over the past century, increasing demands for electric power have led to dam and reservoir construction along many South American rivers. The construction disrupts the natural river ecosystems (Petrere Jr., 1996). For migratory fish species, dam and reservoir construction can change population genetics by splitting populations and isolating previously connected populations. This change in gene flow can reduce the fitness of the population and increase its risk of extinction (Neraas and Spruell, 2001; Frankham et al., 2004; Reid et al., 2008). Two hydroelectric dams (Gafanhoto and Cajuru) have been built on the Pará River, one of São Francisco River's most important tributaries, since the 1940s (Figure 1). Since 1983, P. costatus restocking programs have aimed to reduce the environmental impacts of the dams on the Pará River.

Molecular markers are powerful tools used to study genetic diversity and population differentiation (Avise et al., 1987). Microsatellites or short tandem repeats (STRs) are commonly used molecular markers in population studies (Zane et al., 2002; Yazbeck and Kalapothakis, 2007; Barbosa et al., 2008; Paiva and Kalapothakis, 2008; Hsu et al., 2011). STRs are often divided into several categories on the basis of the repeat pattern. Complex hypervariable repeats are highly polymorphic in natural populations and have many alleles that differ with respect to both length and sequence. These hypervariable markers can be used alone in population studies (Urquhart et al., 1993; Gill et al., 1994; Reid et al., 2003; Butler et al., 2009). 


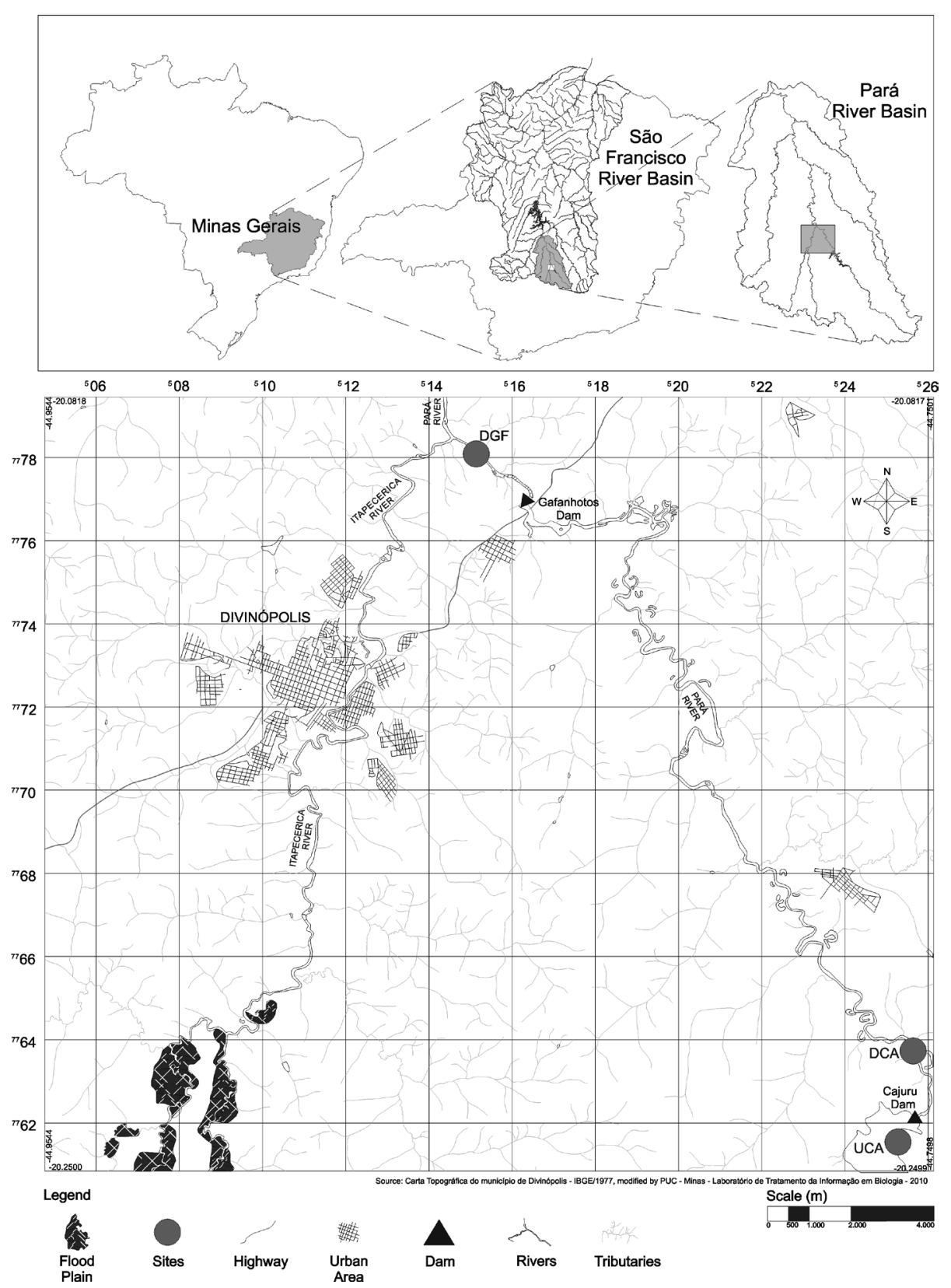

Figure 1. Map of the collection sites in the Pará River Basin. Site I = downstream Gafanhoto Dam (DGF); site II = site between Gafanhoto and Cajuru Dams (DCA); site III = upstream Cajuru Dam (UCA).

To characterize the standing genetic variation and population structure of $P$. costatus in 3 sites in the Pará River, we investigated genetic differentiation by using complex hyper- 
variable repeats. The data can be used as a baseline in future studies to investigate how the restocking program affects the composition, structure, and life cycle of local fish species. In addition, these data can contribute to the development of conservation management programs for these fish.

\section{MATERIAL AND METHODS}

\section{Sample collection}

We collected 45 adult $P$. costatus from the Pará River (Minas Gerais, Brazil) between October 2006 and February 2007. The specimens were collected from 3 distinct sites (Figure 1; Table 1): site I was immediately downstream of the Gafanhoto Dam, site II was between the Gafanhoto and Cajuru Dams, and site III was upstream of the Cajuru Dam. From each specimen, we sampled $1 \mathrm{~cm}^{2}$ of the caudal fin.

\begin{tabular}{|c|c|c|}
\hline Species & Sites & Geographic coordinates \\
\hline P. costatus & Downstream Gafanhoto Dam & $20^{\circ} 05^{\prime} 58^{\prime \prime} \mathrm{S}-44^{\circ} 50^{\prime} 56^{\prime \prime} \mathrm{W}$ \\
\hline P. costatus & Site between Gafanhoto and Cajuru Dams & $20^{\circ} 14^{\prime} 17^{\prime \prime} \mathrm{S}-44^{\circ} 45^{\prime} 13^{\prime \prime} \mathrm{W}$ \\
\hline P. costatus & Upstream Cajuru Dam & $20^{\circ} 15^{\prime} 05^{\prime \prime} \mathrm{S}-44^{\circ} 45^{\prime} 16^{\prime \prime} \mathrm{W}$ \\
\hline
\end{tabular}

Sample sizes: 15 .

\section{DNA extraction, amplification, and analysis of the 2 V35 locus}

The complex hypervariable repeat 2V35 was isolated from a primary genomic library for P. lineatus; the library was constructed using genomic DNA extracted from muscle tissue (Yazbeck and Kalapothakis, 2007) by using the proteinase K-phenol-chloroform method (Sambrook and Russell, 2001).

Genomic DNA was isolated from each sample by digestion with proteinase $\mathrm{K}$ at $37^{\circ} \mathrm{C}$ overnight, followed by standard phenol/chloroform extraction (Sambrook and Russell, 2001). The complex hypervariable repeat $2 \mathrm{~V} 35$ was amplified in all 45 specimens by using nested polymerase chain reaction (PCR) with the following primers: F1, 5'-TAATGATTCTCTTTGC TTGTGTC-3', R1，5'-GCAGACCCCTCAGCAC-3'， F2，5'-TCTTTGCTTGTGTCTTG-3', and R2, 5'-AAGGCCTGAAATACAGTGCA-3'. Each nested PCR was performed using a total volume of $25 \mu \mathrm{L}$ that contained 20-50 ng genomic DNA (first round) or $0.5 \mathrm{ng}$ PCR product (second round), $5 \mathrm{pM}$ of each primer (F1/R1 first round or F2/R2 second round), and a pre-mix containing PCR buffer, dNTPs, and Taq DNA polymerase (Phoneutria Biotecnologia e Serviços, Belo Horizonte, Brazil). The first round had the following cycling conditions: an initial denaturation at $94^{\circ} \mathrm{C}$ for $2 \mathrm{~min}$, followed by 35 cycles of denaturation at $94^{\circ} \mathrm{C}$ for $30 \mathrm{~s}$, primer annealing at $54^{\circ} \mathrm{C}$ for $30 \mathrm{~s}$, and extension at $72^{\circ} \mathrm{C}$ for $40 \mathrm{~s}$, with a final extension step at $72^{\circ} \mathrm{C}$ for $5 \mathrm{~min}$. The second PCR round had similar cycling conditions, except that the annealing temperature was $51^{\circ} \mathrm{C}$. PCR products $(8 \mu \mathrm{L})$ were visualized on a $2 \%$ agarose gel and selected for direct sequencing. The PCR products were sequenced bi-directionally 
by using primers F2 and R2 and the BigDye Terminator v3.1 Cycle Sequencing Kit (Applied Biosystems, Inc., Foster City, CA, USA), following the manufacturer protocol, on an ABI 3130 Genetic Analyzer.

\section{Statistical analysis}

Genetic variation at the intra-population level in indices such as gene diversity, nucleotide diversity, number of observed transitions, transversions, and indels, and the number of haplotypes shared among populations was measured using Arlequin 3.5.1 (Excoffier and Lischer, 2010).

The genetic structure of the population was assessed using hierarchical analyses of molecular variance (AMOVA; Excoffier et al., 1992), which was conducted by imposing 3 different clusters and 1 population group. The source of variation was calculated with respect to partitioning the molecular variance among populations and within populations. Population differentiation was analyzed using Wright's $F_{\mathrm{ST}}$ (Wright, 1951).

\section{Isolation by distance}

Isolation by distance was evaluated by testing the correlation between the genetic and geographic distance matrices with a Mantel test (Mantel, 1967), and 1000 permutations and logarithmic transformations of both distance measures were calculated by the Alleles in Space software (Miller, 2005).

\section{Phylogenetic analysis}

Phylogenetic analyses were conducted using MEGA version 4 (Tamura et al., 2007). The phylogenetic tree was built using a neighbor-joining algorithm (Saitou and Nei, 1987) with the p-distance method (Nei and Kumar, 2000) and by assuming uniform evolutionary rates. The confidence of the resulting topology was estimated by bootstrapping $(10,000$ replicates).

\section{RESULTS}

\section{Diversity indices}

The complex hypervariable repeat $2 \mathrm{~V} 35$ amplified approximately 461 bp in all 45 specimens, and 25-44 substitutions and 5-20 indels were observed, which resulted in 25 unique $P$. costatus haplotypes (Table 2). Most haplotypes were found only at a single site, and few haplotypes were shared. Site III shared Hap 1 and Hap 10 with site I and Hap 16 and Hap 19 with site II.

Transitions, transversions, and indels in 2V35 and overall diversity indices are given in Table 3 for the species. Genetic diversity was highest (0.9264) at site I in the Pará River population (site I), followed by site III upstream of the Cajuru Dam (0.8874), and lowest at site II between the Gafanhoto and Cajuru Dams (0.8736). 


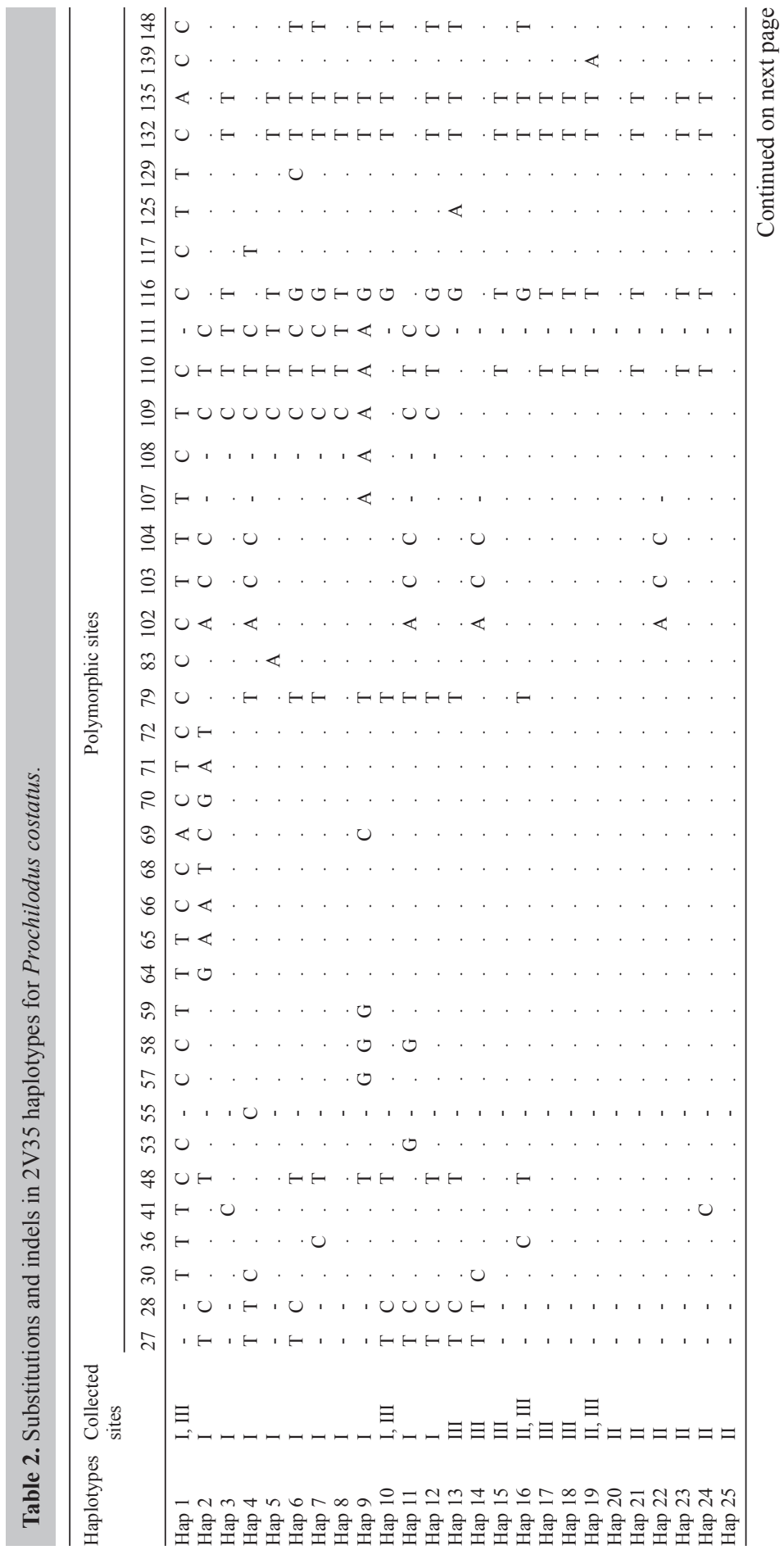


T.M. Barroca et al.

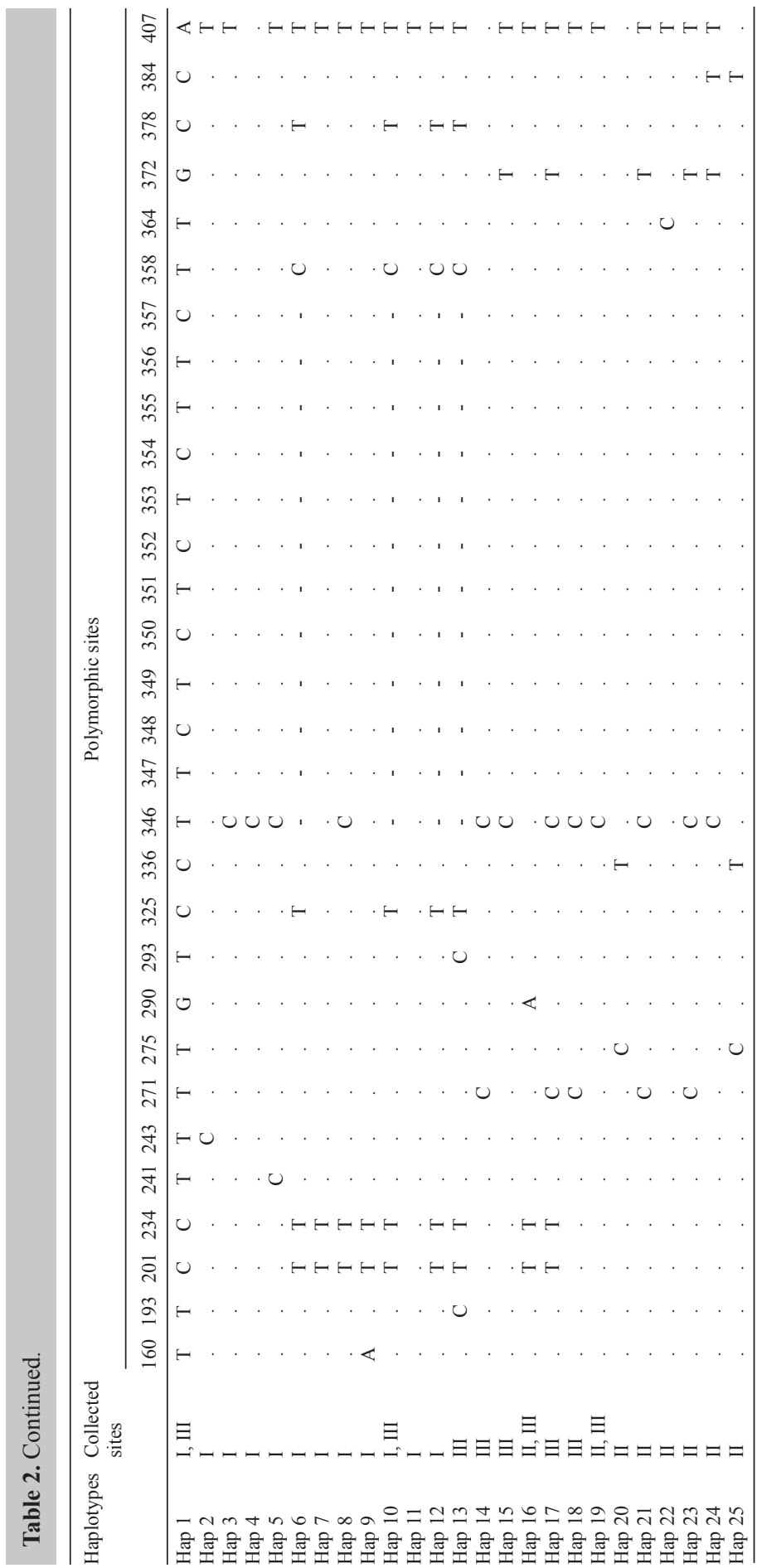


Table 3. Diversity indices at 2V35 in Prochilodus costatus.

\begin{tabular}{lccc}
\hline & \multicolumn{3}{c}{ Sampling localities } \\
\cline { 2 - 4 } & I & II & III \\
\hline P. costatus & & & 27 \\
Substitution & 44 & 25 & 20 \\
Transition & 24 & 19 & 7 \\
Transversion & 20 & 6 & 19 \\
Indels & 20 & 8 & 9 \\
h & 12 & 0.8736 & 0.8874 \\
H & 0.9264 & 0.017420 & 0.035805 \\
$\pi$ & 0.042471 & 5
\end{tabular}

Diversity indices include mutations by transitions, transversions and insertion/deletion polymorphisms (indels); number of haplotypes for sampling localities $(\mathrm{h})$; gene diversity $(\mathrm{H})$; nucleotide diversity $(\pi)$. Sample sizes $=15$.

\section{Population differentiation and structure}

This species showed significant population differentiation at $2 \mathrm{~V} 35$. The $P$. costatus populations had a mean $F_{\text {ST }}$ of 0.16727 . AMOVA results showed that $83.27 \%$ of the genetic variation $(\mathrm{P}<0.05)$ resided within populations (Table 4$)$. Pairwise $F_{\mathrm{ST}}$ values ranged from 0.090 to 0.230 and were significant in all comparisons $(\mathrm{P}<0.05)$ (Table 5).

Table 4. Population differentiation for Prochilodus costatus in the Pará River.
\begin{tabular}{llcccc}
\hline Sample clustering & Source of variation & Degrees of freedom & Variance components & Variation (\%) & Fixation indices \\
\hline Prochilodus costatus & Among populations & 2 & $1.47218 \mathrm{Va}$ & 16.73 & $F_{\mathrm{ST}}=0.16727$ \\
& Within populations & 87 & $7.32912 \mathrm{Vb}$ & 83.27 & \\
\hline
\end{tabular}

$\mathrm{P}<0.05$.

Table 5. Pairwise $F_{\mathrm{ST}}$ values in Prochilodus costatus individuals among the three sampled sites.

\begin{tabular}{lccc}
\hline & I & II & III \\
\hline I & - & 0.00000 & 0.01040 \\
II & $0.23024^{*}$ & - & 0.00000 \\
III & $0.09031^{*}$ & $0.19351^{*}$ & - \\
\hline
\end{tabular}

Pairwise $F_{\mathrm{ST}}$ estimates are presented below the diagonal and $\mathrm{P}$ values are above the diagonal. $* \mathrm{P}<0.05$.

\section{Isolation by distance}

Significant isolation by distance was observed for P. costatus populations (Figure 2; $r=0.196 ; \mathrm{P}<0.001)$.

\section{Phylogenetic analysis}

Phylogenetic reconstruction of 2 V 35 sequences from $P$. costatus revealed 3 strongly supported clusters that were supported by bootstrap values higher than $80 \%$ (Figure 3). 


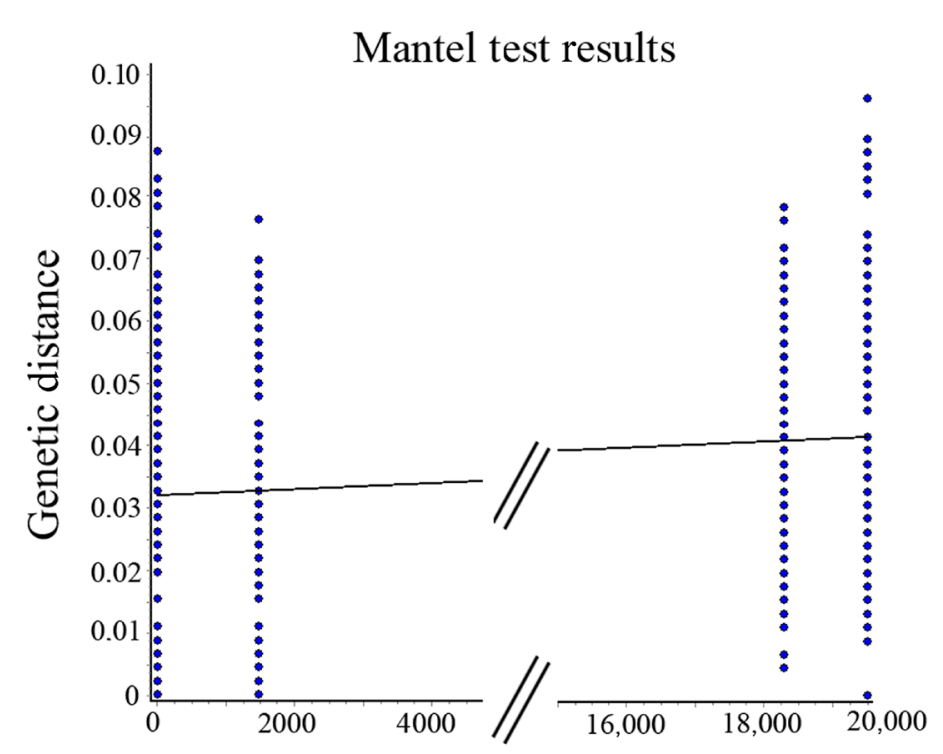

Figure 2. Isolation by distance for Prochilodus costatus $(r=0.196, \mathrm{P}<0.001)$ calculated using the Alleles in Space software (Miller, 2005).

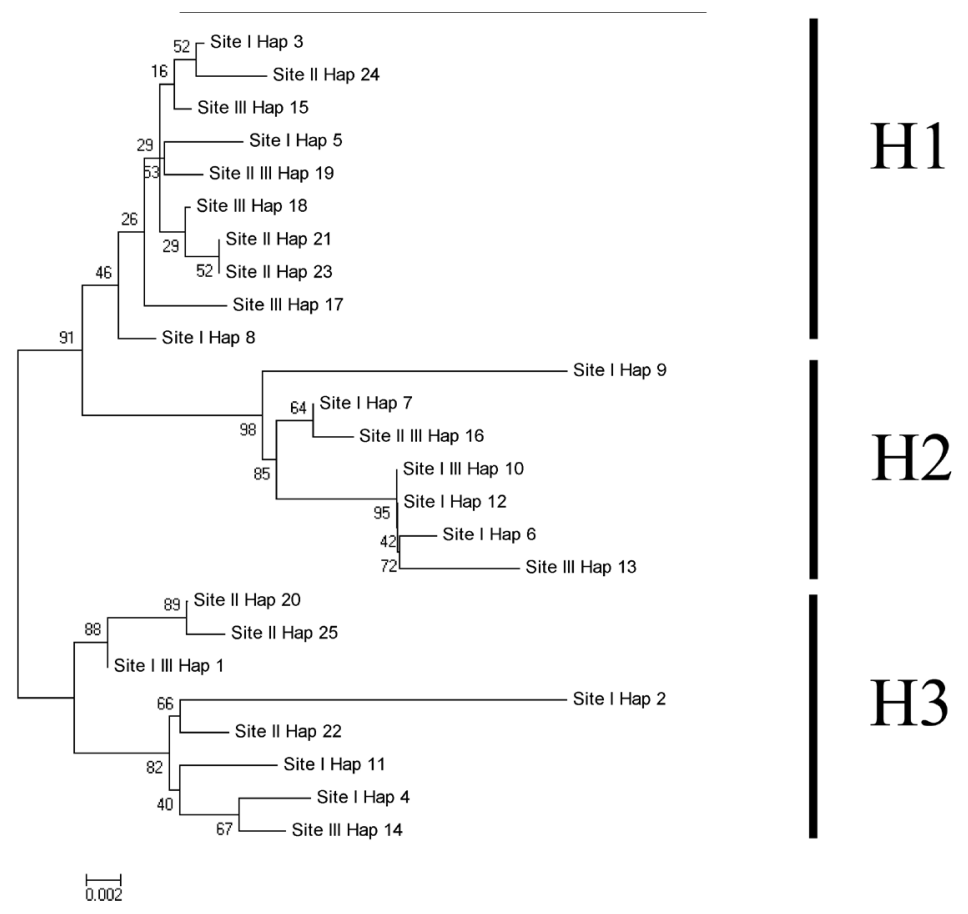

Figure 3. Phylogenetic tree constructed by the neighbor-joining algorithm based on 25 haplotypes of the complex hypervariable repeat 2V35 in Prochilodus costatus. Numbers next to branches indicate bootstrap support of 10,000 replicates. Three clusters are evident. 


\section{DISCUSSION}

We characterized the genetic diversity and population structure for P. costatus, an important endemic fish species of the São Francisco Basin in the Pará River. The molecular marker 2V35 was highly variable across populations, with 25 unique haplotypes from 3 sites in the river. $2 \mathrm{~V} 35$ had no sequence similarity to known proteins (BLASTX; data not shown), and its high level of polymorphism suggested that $2 \mathrm{~V} 35$ is a non-coding, neutrally evolving nuclear marker (Urquhart et al., 1993; Schlötterer, 2000; Zane et al., 2002; Ellegren, 2004; Chenuil, 2006).

Fragmentation of freshwater fish populations by dams may reduce gene flow between populations, leading to lower genetic diversity within populations and significant genetic differentiation among fish populations (Jager et al., 2001; Neraas and Spruell, 2001). Alternatively, no differences may be found between the genetic diversity of above- and below-dam populations (Neraas and Spruell, 2001; Denier et al., 2007). In the present study, P. costatus showed high levels of genetic diversity within and between populations.

The differences in genetic diversity among Pará River P. costatus populations could be the result of the absence of migration caused by the dams, the restocking of hatcheries for over 20 years, and the length of the river fragment. These factors could act independently or together in shaping the population structure of $P$. costatus. The limited number of $2 \mathrm{~V} 35$ haplotypes shared between populations and the significant isolation by distance suggest that there has been little to no gene flow across the 2 dams for more than 6 decades (Santos and Sato, 2012, personal communication). Hatchery programs are widely used to restore declining natural populations. In Brazil, such programs have been in place since the 1970s to restore fish populations and maintain or increase fishery production (Madeira et al., 2005; Agostinho et al., 2007; Araki et al., 2007; Fraser, 2008). Captive breeding programs that use local wild fish as broodstock are expected to produce hatchery fish with minimal differences in fitness from wild fish (Araki et al., 2007). The highly significant genetic differentiation between populations suggests that the Hydrobiology and Pisciculture Station of Três Marias from the Development Company of São Francisco and Parnaíba River has successfully implemented this local approach to generate broodstock. In the captive breeding programs, distinct groups of hatchery fishes are released separately in the 3 sites (Santos and Sato, 2012, personal communication).

The genetic structure of populations in fragmented rivers may change faster than that of populations that inhabit uninterrupted rivers (Reid et al., 2008). In the present study, sites II and III are, in short, river fragments and probably significantly affected by fragmentation. As migratory fishes, $P$. costatus populations at these 2 sites cannot reproduce because of the reduced fragment size and absence of natural conditions for recruitment, such as spawning areas and floods.

Among the 3 sampling sites, site I was the least affected by dams, hatcheries, and river fragmentation. The hatchery fishes from site I were in contact with wild populations from downstream of the Gafanhoto dam, and there were natural conditions for recruitment (Santos and Sato, 2012, personal communication). By contrast, site II was in a short river fragment with barriers to gene flow at both ends and a small population size. Compared to sites I and II, site III was of intermediate length and had an intermediate population size. The observed genetic diversity and structure of the populations at sites II and III was dependent on the genetics of the hatchery fish. 
Variation at the complex hypervariable repeat 2V35 revealed the genetic diversity and structure of $P$. costatus populations. Limited gene flow along the Pará River caused by multiple hydroelectric dams has resulted in large contributions of genetic diversity in the local population from hatchery stocks. Continued monitoring of this species and the hatchery supplementation activity will be important to ensure the maintenance of genetic diversity in fish populations across the São Francisco Basin in the Pará River.

\section{Data accessibility}

DNA sequence GenBank accession No. BankIt1469324 Seq1 JN403076.

\section{ACKNOWLEDGMENTS}

We thank biologists Yoshimi Sato and Gilberto Nepomuceno Salvador for the comments and technical support. Research supported by Fundação de Amparo à Pesquisa do Estado de Minas Gerais (FAPEMIG), Conselho Nacional de Desenvolvimento Científico e Tecnológico (CNPq), Coordenação de Aperfeiçoamento de Pessoal de Nível Superior (CAPES) and Companhia Energética de Minas Gerais (CEMIG). Dr. E. Kalapothakis is the recipient of a CNPq fellowship.

\section{REFERENCES}

Agostinho AA, Vazzoler AEA de M, Gomes LC and Okada EK (1993). Estratificación y comportamiento de Prochilodus scrofa em distintas fases del ciclo de vida, em la planície de inundação del alto rio Paraná y embalse de Itaipu, Paraná, Brasil. Rev. Hydrobiol. 26: 79-90.

Agostinho AA, Gomes LC and Pelicice FM (2007). Ecologia e Manejo de Recursos Pesqueiros em Reservatórios do Brasil. Eduem, Maringá.

Araki H, Cooper B and Blouin S (2007). Genetic effects of captive breeding cause rapid, cumulative fitness decline in the wild. Science 318: 100-103.

Avise JC, Arnold J, Ball R, Bermingham E, et al. (1987). Intraspecific phylogeography: the mitochondrial DNA bridge between population genetics and systematic. Annu. Rev. Ecol. Syst. 18: 489-522.

Barbosa ACDR, Galzerani F, Corrêa TC, Galetti PM Jr, et al. (2008). Description of novel microsatellite loci in the Neotropical fish Prochilodus argenteus and cross-amplification in P. costatus and P.lineatus. Genet. Mol. Biol. 31: 357-360.

Bonetto AA (1986). Fish of the Paraná System. In: The Ecology of River Systems (Davies BR and Walker KF, eds.). Dr. W. Junk, Dordrecht, 573-588.

Bowen SH (1983). Detritivory in Neotropical fish communities. Environ. Biol. Fish. 9: 137-144.

Butler JM, Hill CR, Kline MC, Duewer DL, et al. (2009). The single most polymorphic STR Locus: SE33 performance in U.S. populations. Genet. Suppl. Ser. 2: 23-24.

Chenuil A (2006). Choosing the right molecular genetic markers for studying biodiversity: from molecular evolution to practical aspects. Genetica 127: 101-120.

De Camargo SAF and Petrere M Jr (2001). Social and financial aspects of the artisanal fisheries of Middle São Francisco River, Minas Gerais, Brazil. Fish. Manag. Ecol. 8: 163-171.

Denier K, Garza JC, Coey R and Gorman DJ (2007). Population structure and genetic structure of trout (Onchorynchus mykiss) above and below natural and man-made barriers in the Russian River, California. Conserv. Genet. 8: 437454.

Ellegren H (2004). Microsatellites: simple sequences with complex evolution. Nat. Rev. Genet. 5: 435-445.

Excoffier L and Lischer HE (2010). Arlequin suite ver 3.5: a new series of programs to perform population genetics analyses under Linux and Windows. Mol. Ecol. Resour. 10: 564-567.

Excoffier L, Smouse PE and Quattro JM (1992). Analysis of molecular variance inferred from metric distances among 
DNA haplotypes: application to human mitochondrial DNA restriction data. Genetics 131: 479-491.

Flecker AS (1996). Ecosystem engineering by a dominant detritivore in a diverse tropical stream. Ecology 77: 1845-1854. Frankham R, Ballou JD and Briscoe DA (2004). A Primer of Conservation Genetics. Cambridge University Press, Cambridge.

Fraser DJ (2008). How well can captive breeding programs conserve biodiversity? A review of salmonids. Evol. Appl. 1: 535-586.

Gill P, Kimpton C, D'Aloja E, Andersen JF, et al. (1994). Report of the European DNA profiling group (EDNAP)-towards standardisation of short tandem repeat (STR) loci. Forensic Sci. Int. 65: 51-59.

Hsu T-H, Guillén Madrid AG, Burridge CP, Cheng H-Y, et al. (2011). Resolution of the Acanthopagrus black seabream complex based on mitochondrial and amplified fragment-length polymorphism analyses. J. Fish Biol. 78: 1182-1192.

Jager HI, Chandler JA, Lepla KB and Van Winkle W (2001). A theoretical study of river fragmentation by dams and its effects on white sturgeon populations. Environ. Biol. Fish 60: 347-361.

Madeira MJ, Gómez-Moliner B and Barbe A (2005). Genetic introgression on freshwater fish populations caused by restocking programmes. Biol. Invasions 7: 117-125.

Mantel N (1967). The detection of disease clustering and a generalized regression approach. Cancer Res. 27: 209-220.

Miller MP (2005). Alleles in Space (AIS): computer software for the joint analysis of interindividual spatial and genetic information. J. Hered. 96: 722-724.

Nei M and Kumar S (2000). Molecular Evolution and Phylogenetics. Oxford University Press, New York.

Neraas LP and Spruell P (2001). Fragmentation of riverine systems: the genetic effects of dams on bull trout (Salvelinus confluentus) in the Clark Fork River system. Mol. Ecol. 10: 1153-1164.

Paiva AL and Kalapothakis E (2008). Isolation and characterization of microsatellite loci in Pimelodus maculatus (Siluriformes: Pimelodidae). Mol. Ecol. Resour. 8: 1078-1080.

Petrere M Jr (1996). Fisheries in large tropical reservoirs in South America. Lake Reservoirs: Res. Manag. 2: 111-133.

Reid SM, Wilson CC, Mandrak NE and Carl LM (2008). Population structure and genetic diversity of black redhorse (Moxostoma duquesnei) in a highly fragmented watershed. Conserv. Genet. 9: 531-546.

Reid TM, Ingala DA, Kraemer CM, Dage WM, et al. (2003). Distribution of HUMACTBP2 (SE33) alleles in three North American populations. J. Forensic Sci. 48: 1422-1423.

Saitou N and Nei M (1987). The neighbor-joining method: a new method for reconstructing phylogenetic trees. Mol. Biol. Evol. 4: 406-425.

Sambrook J and Russell D (2001). Molecular Cloning: A Laboratory Manual. 3rd edn. Cold Spring Harbor Laboratory Press, Cold Spring Harbor.

Sato Y and Godinho HP (2003). Migratory Fishes of the São Francisco River. In: Migratory Fishes of South America: Biology, Fisheries and Conservation Status (Carolsfeld J, Harvey B, Ross C and Baer A, eds.). World Fisheries Trust, Victoria, 195-232.

Schlötterer C (2000). Evolutionary dynamics of microsatellite DNA. Chromosoma 109: 365-371.

Sivasundar A, Bermingham E and Ortí G (2000). Population structure and biogeography of migratory freshwater fishes (Prochilodus: Characiformes) in major South American rivers. Mol. Ecol. 10: 407-417.

Tamura K, Dudley J, Nei M and Kumar S (2007). MEGA4: molecular evolutionary genetics analysis (MEGA) software version 4.0. Mol. Biol. Evol. 24: 1596-1599.

Urquhart A, Kimpton CP and Gill P (1993). Sequence variability of the tetranucleotide repeat of the human beta-actin related pseudogene H-beta-Ac-psi-2 (ACTBP2) locus. Hum. Genet. 92: 637-638.

Welcomme RL (1979). Fisheries Ecology of Floodplain Rivers. Logman Group Limited, London.

Wright S (1951). The genetical structure of populations. Ann. Eug. 15: 323-354.

Yazbeck GM and Kalapothakis E (2007). Isolation and characterization of microsatellite DNA in the piracema fish Prochilodus lineatus (Characiformes). Genet. Mol. Res. 6: 1026-1034.

Zane L, Bargelloni L and Patarnello T (2002). Strategies for microsatellite isolation: a review. Mol. Ecol. 11: 1-16. 